\title{
Implementation of Full Time Equivalent Method in Determining the Workload Analysis of Logistics Admin Employees of PT X in Jakarta, Indonesia
}

\author{
Satrio Wicaksono and Alnisa Min Fadillah
}

\section{ABSTRACT}

PT $X$ is a company engaged in distribution and trading as its business activities. The logistics division, especially the logistics admin as a supply chain, certainly, has a big responsibility. In order to carry out this great responsibility, an appropriate number of workers is needed so that the work carried out can be executed properly. In this study, the main objective is to analyze the workload that exists in the current logistics admin employees and later from the results of the workload analysis, a human resource policy can be drawn concerning workloads setting.

The method used in this study was the Full-Time Equivalent (FTE) method where this method could show how much workload is proportional to each employee. As a result, the workload received by each logistics admin employee has a different workload from one employee to another. Of the three existing logistics admin employees, 2 were overloaded and one was inloaded. Human resource policies related to workload arrangements for PT X logistics admin employees can be said to have not been maximized due to differences in workloads for each employee even though each of them does the same job.

Keywords: Full Time Equivalent. HR Policy, Workload.

\section{INTRODUCTION}

A workload is a collection or number of activities that must be carried out by a unit within the organization or position holder within a predetermined period [1]. In the workload, there are 3 levels to classify it, namely workload above normal (overload), normal workload (inload), and workload below normal (underload). A good workload is a proportional workload, neither too much nor too little. If the workload given to employees is too heavy, then the output produced will not be maximal, whereas if the workload given to employees is too light, then the potential of employees cannot be channeled to the fullest. Both of these things do not have a good impact on the company because they will affect how effectively and efficiently the company runs.

In order to make the company allocating the workload appropriately for each employee, an activity called an analysis of the workload that exists within the company is carried out. Workload analysis is a human resource planning activity that aims to determine the power requirements so that organizational goals can be achieved [2].

PT $X$ is a subsidiary of a State-Owned Enterprise (BUMN) which is engaged in distribution and trading as its business activities. Admin employees in the logistics department are the main focus in this research because this section deals directly with the distribution process which is one of the company's main processes, namely the
Submitted : August 28, 2021

Published : September 27, 2021

ISSN: $2507-1076$

DOI: $10.24018 /$ ejbmr.2021.6.5.1076

\section{Satrio Wicaksono*}

Universitas Pembangunan Nasional

Veteran Jakarta, Indonesia.

(e-mail: satriow@upnvj.ac.id)

Alnisa Min Fadillah

Universitas Pembangunan Nasional

Veteran Jakarta, Indonesia.

(e-mail: alnisaminfadlillah@ ${ }^{\text {upnvj.ac.id) }}$

*Corresponding Author distribution of consumer products, pharmaceutical products, plantation products as well as plantation tools, and facilities which are distributed to consumers through PT X branch offices.

After conducting interviews with the company, they stated that in the implementation related to human resource management, PT X had not carried out workload analysis activities before. Therefore, PT $\mathrm{X}$ wants to start doing workload analysis to find out whether the company has been effective and efficient in providing workloads to its employees.

Of the many methods that can be used to analyze workloads, there is a method called the Full-Time Equivalent (FTE) method. The results of the workload analysis calculation through the FTE method will produce output whether some workers or employees get overload or underload workloads.

\section{A. Research Objectives}

This study aims to determine the workload of each employee, the optimal number of workers, and human resource policies related to managing the workload of PT X admin employees in the logistics department.

\section{B. Research Scope and Limitations}

This research was only conducted on the admin staff of the logistics department. This study was focus only on the workload received at the time the research was conducted, excluding past and future workloads, as well as the input 
provided on overtime arrangements, job redesign, adding or reducing the number of employees.

\section{LITERATURE REVIEW}

\section{A. Workload Analysis}

Workload analysis is a stage of the analysis process of the time used by an incumbent in completing a job given to them which is carried out under normal conditions and situations [3]. In addition, the government has set regulations that explain the workload analysis listed in the Regulation of the Minister for State Apparatus Empowerment and Bureaucratic Reform of the Republic of Indonesia No. 1 of 2020 concerning Guidelines for Job Analysis and Workload Analysis where "Workload Analysis is a management technique that is carried out systematically to obtain information about the level of effectiveness and efficiency of an organization's work based on work volume".

\section{B. Full-Time Equivalent (FTE)}

In analyzing the workload, a method is needed, and of the many methods that can be used to analyze the workload, there is a method called the Full-Time Equivalent (FTE) method. The Full-Time Equivalent method is a workload analysis method by calculating the workload ratio [4]. In the calculation process, the FTE method compares the time required to complete a job compared to the available effective working time [3]. Based on the workload analysis guidelines set by the National Civil Service Agency in 2010, the FTE index is divided into 3 types, namely:

$$
\begin{array}{lll}
- & \text { Underload } & : 0-0.99 \\
\text { - Inload } & : 1-1.28 \\
\text { - Overload } & :>1.28
\end{array}
$$

The first step in calculating the workload analysis using the FTE method is, firstly, to find the Total Activity Time which can be obtained through:

Total Activity Time $=\Sigma$ Main Activity +

$\Sigma$ Supporting Activity $+\Sigma$ Incidental Activity

After the Total Activity Time is obtained, then a new calculation is carried out to get the FTE value from a work process, where:

$$
F T E=\frac{\left(\sum \text { Activity Time }+ \text { Allowance }\right)}{\sum \text { Time Available }}
$$

\section{HR Policy on Workload Management}

Human Resources Management Policies are ongoing guidelines on the approach, which a company wants to adopt in managing its employees. The policy defines the organization's philosophy and values on how employees should be treated, which then becomes the manager's guide for dealing with HR-related issues [5]. An HR policy can help the company to ensure that when dealing with a problem, the approach used is in line with the company's values because the policy guides what managers should do in certain circumstances or situations.

\section{METHOD}

In this study, the method used was qualitative research with the type of case study research explored is a phenomenon or case from a certain period and activity (can be in the form of programs, processes, institutions, or social groups), as well as collecting detailed information using various data collection procedures during the case [6]. The data processing of this research was a qualitative descriptive analysis, where all data are expressed in the form of statements or not numeric. In this approach, researchers also need data from the subject. In this study, the researcher would take data that describes the subject, the respondent, such as profile (name, gender, age, and position) and scope of work responsibilities [7].

There were two types of data used in this study, namely primary data and secondary data. Primary data is data collected and obtained directly through the source or respondents through data collection techniques. While secondary data is data obtained indirectly, generally obtained from object documentation such as organizational profiles, activities, and developments [8].

The participants involved in this study were three employees, all of whom were in the admin position in the logistics section and the HR manager. During the interview process, the researcher recorded the conversations that had been done and obtained about 53 pages of interview transcripts. To further explore the case under study, the research was also supported by secondary data, such as the job description of each employee and the amount of allowance set by the company. After the data obtained has been collected, then the Full-Time Equivalent (FTE) calculation was carried out for each employee.

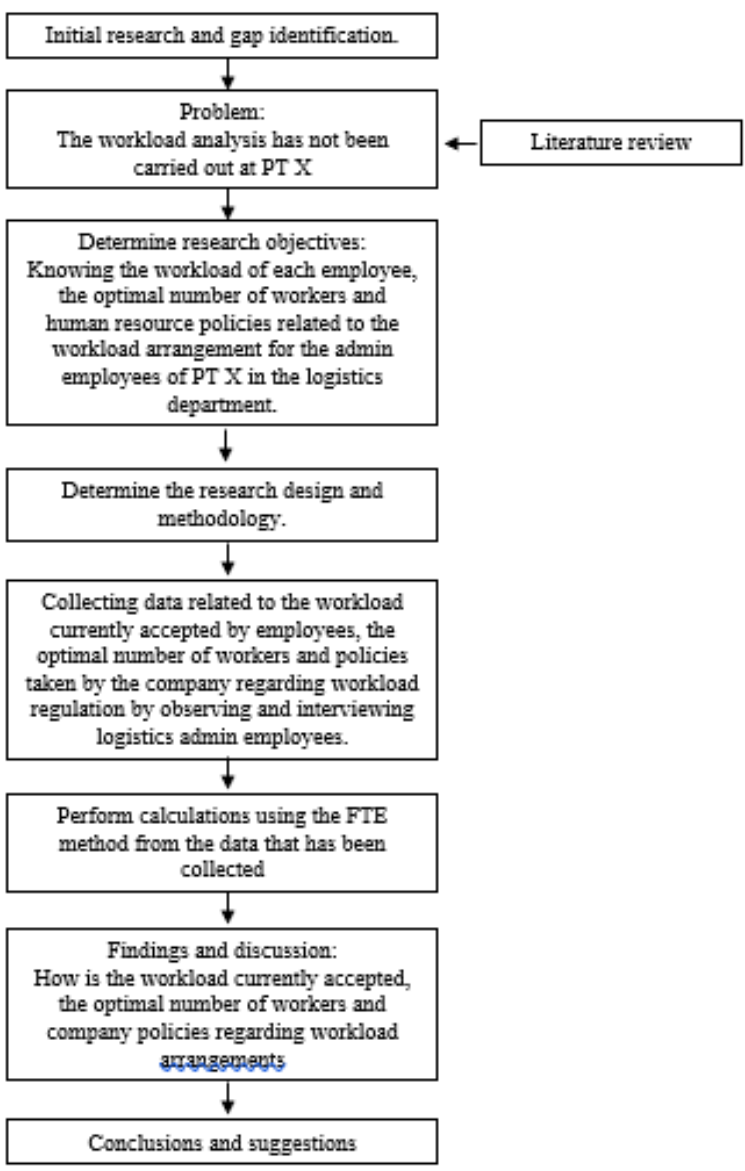




\section{FINDING AND RESULT}

\section{A. Workload Received by Employees}

\section{Number of Days Available}

Before the researcher calculates the workload on the logistics admin staff, the researcher must first know the working days apply to PT X as follows:

\begin{tabular}{cc} 
TABLE I: TOTAL WORKING DAYS IN A YEAR \\
\hline \hline Description & Total (days) \\
\hline One year & 365 \\
Saturday \& Sunday & 94 \\
Annual leave & 12 \\
Holidays (National/official day-off & 13 \\
\& National Holidays)* & 246 \\
Total &
\end{tabular}

Based on the revised SKB 2021, the holidays for 2021 are 16 days. But because there are 2 days off on Saturday and one on Sunday so it was not included in the calculation.

\begin{tabular}{cc} 
TABLE II: NUMBER OF MINUTES WORKING IN A YEAR \\
\hline \hline Description & Minutes \\
\hline One day & 480 \\
One week & 2400 \\
One month & 9600 \\
One year & 118080 \\
\hline \hline
\end{tabular}

\section{Allowance}

\begin{tabular}{ccc}
\multicolumn{3}{c}{ TABLE III: ALLOWANCES PT X } \\
\hline \hline Factors & Categories & Leniencies \\
\hline Energy Expended & $\begin{array}{c}\text { Work on desk } \\
\text { Continuously looking } \\
\text { Eye fatigue }\end{array}$ & $4 \%$ \\
Personal needs & $\begin{array}{c}\text { Urination \& other } \\
\text { needs }\end{array}$ & $3 \%$ \\
\hline \hline
\end{tabular}

After knowing the Allowance of $12.5 \%$, the next step was to find out the value of Allowance for one year. In order to find out the Allowance for one year were as follow:

\section{Allowance $=$ Leniency $\mathrm{x}$ Total days a year $\mathrm{x}$ Work hours a day \\ Allowance $=12,5 \% \times 246$ Days x 480 (minutes) \\ Allowance $=14760$ minutes \\ 3. FTE Calculation}

After obtaining data related to the workload carried by participants as logistics admin employees for one year, only workload analysis can be carried out using the Full-Time Equivalent (FTE) method. By using the FTE formula, the results obtained were as follows:

\begin{tabular}{|c|c|c|c|c|}
\hline Description & $\begin{array}{c}\text { Total } \\
\text { (Days) }\end{array}$ & Allowance & $\begin{array}{c}\text { Time } \\
\text { Available }\end{array}$ & FTE Index \\
\hline $\begin{array}{l}\text { Logistic } \\
\text { Admin } 1\end{array}$ & 154,856 & 14,760 & 118,080 & 1.44 \\
\hline $\begin{array}{l}\text { Logistic } \\
\text { Admin } 2\end{array}$ & 184,596 & 14,760 & 118,080 & 1.69 \\
\hline $\begin{array}{l}\text { Logistic } \\
\text { Admin } 3\end{array}$ & 105,608 & 14,760 & 118,080 & 1.02 \\
\hline \multicolumn{4}{|c|}{ TOTAL } & 4.15 \\
\hline
\end{tabular}

\section{B. Optimal Number of Workforce}

The optimal workload is a workload that is neither overloaded nor underloaded. If employees carry a too heavy workload of course it will not have a good impact, especially for employees and the organization because the output produced will not be optimal [9]. In getting a report related to how much work optimization of a company is seen based on how many tasks need to be completed within a certain time, a workload measurement is carried out [10].

To find out the optimal workforce needed, a calculation was carried out using the Full-Time Equivalent (FTE) method. From the calculation, it is known that there was no balance in the workload. From three employees, two of them were categorized as having a workload that exceeds the normal limit or overload, while one other employee has a normal workload or inload. The total workload FTE index of the three employees was 4.15 or on average one employee has a load of 1.38. From this figure, the logistics admin employees were said to be overloaded because they exceed the inload index which was 1-1.28. Thus, from the FTE calculation, the optimal number of employees in the logistics section admin was 4 people or an additional logistics section admin employee where each employee will have a burden of 1.04 .

\section{Human Resources Policy Regarding Workload Management}

An HR policy could help the company to ensure that when dealing with an employee-related issue, the approach is in line with company values. Because the policy guides what managers should do in certain circumstances or situations [11].

Especially in terms of workload regulation, of course, the company needs to make a policy regarding how the workload should be carried out. At PT X, the policies applied were still not optimal, which can be seen between one employee and another employee that has not been divided equally. The workload arrangement was not further broken down, but only limited to the distribution of principals. In fact, each principal sells different goods, some principals sell fast-moving goods such as masks \& hand sanitizers and some sell slow-moving goods such as humidifiers, air purifiers, and other medical devices.

Even though the logistics manager has tried to divide the workload equally, but in my personal opinion, this division of workload is still not appropriate. To divide it equally, they need to look further at the type of the product, whether it is a fast-moving product or a slow-moving product. Don't delegate only one employee to handle fast-moving products where the turnover is fast, many purchase orders (PO), while other employees are given slow-moving products.. (admin employee 1)

One of the policies that can be done by the company to cope with employee overload was the overtime program.

For overload, I first looked at the environment, whether there was work that could be delegated to other employees who were still underloaded. However, if the job delegation is still overloaded, maybe we can consider doing an overtime program if the overtime hours are still within the corridor of the law... (HR Manager) 
In formulating policies related to overtime, the policies made by the company must be following the laws and regulations that exist within the government which can be regulated in the Act of Republic of Indonesia number 11 of 2020 concerning Job Creation in Article 78 paragraph 1 and Government Regulation of the Republic of Indonesia No. 35 of 2021 concerning Work Agreements for Certain Time, Outsourcing, Working Time and Rest Time, and Termination of Employment Article 26 wherein essence overtime may be applied if there is an agreement between the employee concerned and the maximum overtime time is 4 hours a day and or 18 hours a week. If the company applies overtime in excess of these provisions, it can be ascertained that the company violates the laws and regulations. In addition to doing overtime, the company can also redesign jobs, so that the division of work is more appropriate, or recruit additional employees if needed [11].

\section{CONCLUSION}

Based on the results of the research that has been conducted, it can be concluded that:

1) The workload received by each logistics admin employee has a different workload from one employee to another. Of the three logistics admin employees, the first employee has a workload of 1.44; then the second logistics admin employee has a workload of 1.69 , and the third logistics admin employee has a workload of 1.02.

2) The workload of the three logistics admin employees was still not balanced. From the three employees, two of them were categorized as having a workload that exceeds the normal limit or overload, while one other employee has a normal workload or inload. Based on the FTE calculation, the optimal number of workers for the logistics admin employee is 4 people or one additional logistics admin employee.

3) Human resource policies related to workload arrangements for logistics admin employees of PT Rajawali Nusindo Jakarta can be said to have not been maximized due to differences in workloads for each employee even though each of them does the same job. The delegation of tasks was only limited to the same number of principals, but it was not seen whether the items they were responsible for are items in the fast-moving, medium moving, or slowmoving categories. Therefore, the existing workload sharing policy still needs to be studied further.

Suggestions that can be given to companies are logistics managers and HR managers need to review in determining human resource policies related to the workload for each employee.

Related to this, if there is an overload, the company can first examine whether the overload can still be overcome by implementing an overtime policy which is of course in accordance with the legal corridor. within the government which can be regulated in the Republic of Indonesia Law no. 11 of 2020 concerning Job Creation in Article 78 paragraph 1 and Government Regulation of the Republic of Indonesia No. 35 of 2021 concerning Work Agreements for Certain Time, Outsourcing, Working Time and Rest Time, and Termination of Employment Article 26.

If it turns out that it is not possible to do overtime, job redesign can be done, such as dividing principals or suppliers based on more detailed categories, starting from the type of item being sold and the characteristics of the item, whether the item is fast-moving, medium moving, or slow-moving.

If it turns out that the job redesign is still overloaded, then the last step that can be taken by PT Rajawali Nusindo Jakarta is to add manpower or recruitment, but this must still be considered further, whether this overload occurs continuously or temporarily, if it turns out that this overload is temporary or temporary, it is better if the employees recruited are PKWT (Specific Time Work Agreement) or contract employees.

\section{REFERENCES}

[1] N. Hudaningsih and R. Prayoga, "Analisis Kebutuhan Karyawan Dengan Menggunakan Metode Full Time Equivalent ( FTE ) Pada Departemen Produksi PT. Borsya Cipta Communica," J. Tambora, vol. 3, no. 2, pp. 98-106, 2019.

[2] D. T. Wardanis, "Analisis Beban Kerja Tenaga Rekam Medis Rumah Sakit Bedah SurabayaMenggunakan Metode FTE," J. Adm. Kesehat Indones., vol. 6, no. 1, p. 53, 2018, doi: 10.20473/jaki.v6i1.2018.53 60.

[3] M. Zekben and H. Prastawa, "Penentuan Beban Kerja dan Kebutuhan Tenaga Kerja dengan menggunakan Metode FTE (Full Time Equivalent) pada Bagian Produksi Non Betalaktam (Tablet Tablet Salut Kapsul) PT Phapros Tbk," vol. 6, no. 3, 2017.

[4] A. Bairizki, Manajemen Sumber Daya Manusia (Tinjauan Strategis Berbasis Kompetensi) - Jilid 2, 2nd ed. Jakarta: Pustaka Aksara, 2020.

[5] M. Armstrong, A Hand Book of Human Resource Management Practice, vol. 10. London: Kogan Page, 2012.

[6] UPNVJ, "Pedoman Penulisan Skripsi TA 2020/2021 Fakultas Ekonomi dan Bisnis." 2021.

[7] Sugiyono, Metode Penelitian Pendidikan Pendekatan Kuantitatif, Kualitatif dan $R \& D$, 22nd ed. Bandung: ALFABETA, 2015.

[8] Raihan, "Metodologi Penelitian," J. Chem. Inf. Model., vol. 53, no. 9, pp. 1689-1699, 2019.

[9] R. Irawati and D. A. Carollina, "Analisis Pengaruh Beban Kerja Terhadap Kinerja Karyawan Operator Pada Pt Giken Precision Indonesia," Inovbiz J. Inov. Bisnis, vol. 5, no. 1, p. 51, 2017, doi: 10.35314/inovbiz.v5i1.171.

[10] E. Mahawati et al., Analisis Beban Kerja dan Produktivitas Kerja. Yayasan Kita Menulis, 2021

[11] A. Subyantoro, Manajemen Sumber Daya Manusia Strategi. Yogyakarta: Penerbit Andi, 2020.

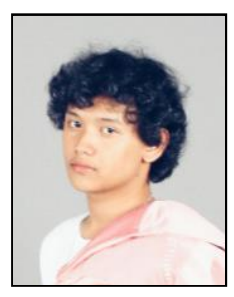

S. Wicaksono is a graduate student in human resource management at the University of Pembangunan Nasional Veteran, Jakarta. He was born in Tangerang, November 16, 1999. He is interested in matters related to human resources and marketing. in the next few years, he dreams of becoming an expert in the field of human resources.

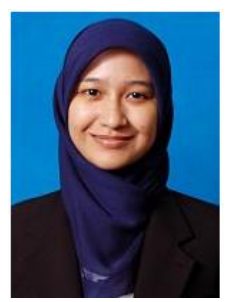

Alnisa Min Fadlillah is a Lecturer in the Faculty of Economics and Business at the University of Pembangunan Nasional Veterans Jakarta. Higher education was obtained at the Graduate School of Business, National University of Malaysia (UKM) and earned a Master Degree of Business Administration (M.BA) in 2014. The author also holds a CHRP degree, Certified Human Resource Professional and as a Human Resource Management Assessor at Professional Certification Institute (LSP) UPN Veterans Jakarta certified by BNSP. 